\title{
ALA reorganization destined for further study: Actions at ALA Council, Chicago, 1995
}

At the ALA Annual Conference in Chicago in June, the ALA Council voted not to reorganize the association at the present time but to continue to study the possibility. A plan to reorganize ALA was proposed by the Organizational Self Study Committee (OSSC) during the spring. A slightly revised version was released at conference. The subject of impassioned discussion in the exhibits, at cocktail parties, and during caucuses all over ALA Chicago, the proposed restructuring was met with criticism it never overcame. Problems resulting from the current structure were never identified, so it was impossible to tell if the proposed structure would improve ALA.

Additional concerns included the lack of time for membership input (the plan was never published in American Libraries, for example), the radical restructuring of roundtables and type-of-activity sections, the lack of Council restructuring as a corollary to the ALA proposal, and the lack of a budget impact statement. Members of the OSSC took this criticism well, offering the explanation that this proposal was intended to "get discussion started." It certainly did that.
Council created a Structural Revision Task Force to review the proposal, to offer additional options for reorganization, to oversee public hearings at AlA in New York next summer, and to present new recommendations for restructuring ALA to Council in San Francisco in 1997. The Task Force will no doubt benefit from the hard work done by the OSSC and learn from the failed attempt at ratification this summer.

In another important Council action, the Intellectual Freedom Commitree's "Access to Electronic Information, Services, and Networks: An Interpretation of the Library Bill of Rights" was sent back to committee in order to gain input and consensus on the provisions and wording. Urging that the proposed draft was too hastily composed and included provisions which were unreasonable and unworkable in many libraries, ACRL was joined by representatives of the Library and Information Technology Association and many other members of Council involving this action. A new draft of the statement should be ready by Midwinter for reconsideration.W. Lee Hisle, ACRL Councillor
"Guidelines for Instruction Programs" is available for your review at http://ux1.cso.uiuc.edu/ - bswoodar/guidelin.html. A print copy of the final draft will be published in the December 1995 issue of CERL News. This is the first revision to the "Guidelines for Bibliographic Instruction" since its approval in 1977.

\section{Wedding doesn't stop conference attendance}

Mary Lou Goodyear, ACRL member and the 1995-96 ALA Reference and Adult Services Division (RASD) president, was married during the 1995 ALA Annual Conference in Chicago. Goodyear married Adrian Alexander, director of western region sales for the Faxon Company, on June 22 at the Doral Plaza Hotel. Goodyear, senior associate director at the Texas A\&M University Library, said she wanted to have both fam- ily and friends at her wedding and chose the ALA Annual Conference as the perfect place. Following the conference, the couple honey-

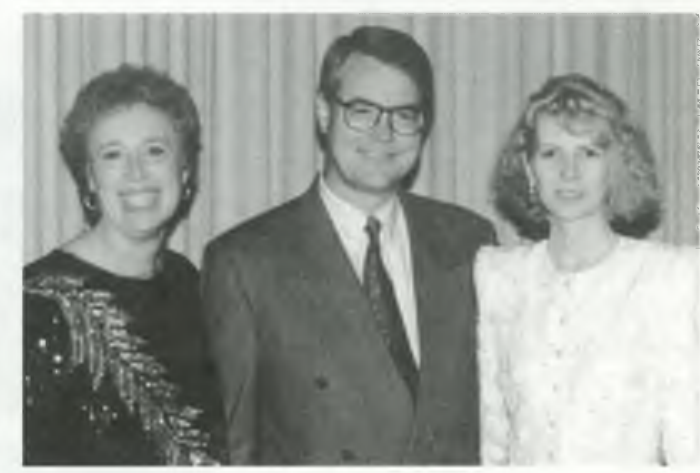

Married at the ALA Annual Conference were ACRL member Mary Lou Goodyear (right) and Adrian Alexander (center). RASD executive director Cathleen Bourdon is at left. 